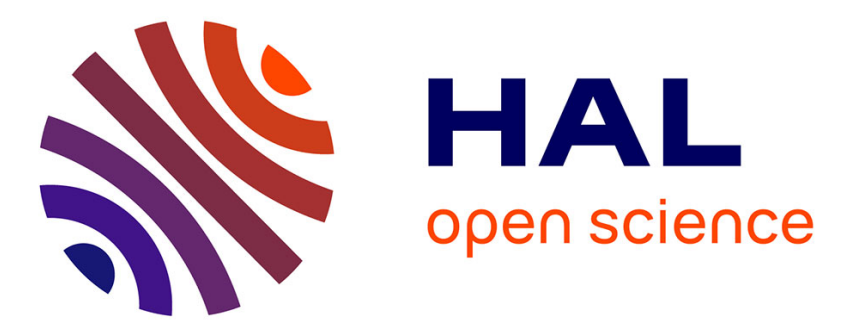

\title{
Broca and Charcot's Research on Jacques Inaudi:The Psychological and Anthropological Study of a Mental Calculator
}

Serge Nicolas, Alessandro Guida, Zachary Levine

\section{- To cite this version:}

Serge Nicolas, Alessandro Guida, Zachary Levine. Broca and Charcot's Research on Jacques Inaudi:The Psychological and Anthropological Study of a Mental Calculator. Journal of the History of the Neurosciences, 2013, 23 (2), pp.140 - 159. 10.1080/0964704x.2013.840751 . hal-01874130

\section{HAL Id: hal-01874130 \\ https://hal.univ-rennes2.fr/hal-01874130}

Submitted on 14 Sep 2018

HAL is a multi-disciplinary open access archive for the deposit and dissemination of scientific research documents, whether they are published or not. The documents may come from teaching and research institutions in France or abroad, or from public or private research centers.
L'archive ouverte pluridisciplinaire $\mathbf{H A L}$, est destinée au dépôt et à la diffusion de documents scientifiques de niveau recherche, publiés ou non, émanant des établissements d'enseignement et de recherche français ou étrangers, des laboratoires publics ou privés. 


\title{
Journal of the History of the Neurosciences
}

\author{
Basic and Clinical Perspectives
}

\section{Broca and Charcot's Research on Jacques Inaudi:The Psychological and Anthropological Study of a Mental Calculator}

\section{Serge Nicolas, Alessandro Guida \& Zachary Levine}

To cite this article: Serge Nicolas, Alessandro Guida \& Zachary Levine (2014) Broca and Charcot's Research on Jacques Inaudi:The Psychological and Anthropological Study of a Mental Calculator, Journal of the History of the Neurosciences, 23:2, 140-159, DOI: 10.1080/0964704X.2013.840751

To link to this article: https://doi.org/10.1080/0964704X.2013.840751

\section{曲 Published online: 03 Apr 2014.}

\section{Submit your article to this journal ๘}

LII Article views: 109

View Crossmark data $\nearrow$

Citing articles: 5 View citing articles $\widetilde{ }$ 


\title{
Broca and Charcot's Research on Jacques Inaudi:The Psychological and Anthropological Study of a Mental Calculator
}

\author{
SERGE NICOLAS, ${ }^{1}$ ALESSANDRO GUIDA, ${ }^{2}$ \\ AND ZACHARY LEVINE ${ }^{3}$ \\ ${ }^{1}$ Paris Descartes University, Paris, France \\ ${ }^{2}$ University of Rennes 2, Rennes, France \\ ${ }^{3}$ Columbia University, New York, USA
}

\begin{abstract}
In the nineteenth century, French scientific institutions became interested in young "mental calculators," arithmetical prodigies able to quickly and accurately perform complex mental calculations. The first scientists to study mental calculators were phrenologists who sought to prove the existence of a calculating organ in the frontal lobe. Paul Broca introduced one such mental calculator, Jacques Inaudi, to the Anthropological Society of Paris in 1880. Broca attributed extraordinary faculty for mental calculation to memory functioning (the psychological hypothesis) rather than physiological difference (the phrenological hypothesis). In 1892, prominent French Academy of Sciences member Jean-Martin Charcot produced a noteworthy study of Inaudi on the organization's behalf. Charcot observed that Inaudi called upon auditory memory rather than visual memory in his mental calculations, unlike most mental calculators who preceded him. Like Broca, Charcot was skeptical of the phrenological hypothesis, though he noted that Inaudi's skull was markedly plagiocephalic. Interestingly, anthropological examination of Inaudi is consistent with the themes of modern cognitive neuroscience. Thus, Charcot seems to have anticipated present research on the localization of mental calculation and memory for numbers.
\end{abstract}

Keywords Inaudi, Broca, Charcot, phrenology, psychology, memory, mental calculator

In the nineteenth century, the French Académie des Sciences (Academy of Sciences) ${ }^{1}$ took up the study of "mental calculators," prodigies capable of performing complex mathematical operations using only their minds. It was the only institution in Europe to have shown serious interest in studying the calculators' psychology and mental processes. The first young mental calculator presented at the Academy of Sciences was an American boy named Zerah Colburn (1804-1839), who was examined by mathematician Pierre-Simon de Laplace (1749-1827) in 1814. Franz Josef Gall (1758-1828), who later examined

${ }^{1}$ The Academy of Sciences, founded in 1666 by Louis XIV (1638-1715) with the goal of contributing to the advancement and application of the sciences in France, was one of the earliest European scientific institutions. As a prestigious society, it played an active role in defining scientific and technological research policy as well as drafting and publishing official reports.

Address correspondence to Serge Nicolas, Institut de Psychologie, Laboratoire Mémoire et Cognition, 71 avenue Edouard Vaillant, 92774 Boulogne-Billancourt Cedex, France. E-mail: serge.nicolas@ parisdescartes.fr 
Colburn's skull in Paris, believed that Colburn confirmed his phrenological hypothesis ${ }^{2}$ of the existence of a special calculating organ (Gall, 1819, 1825). Thereafter, the Academy of Sciences also studied Mangiamele in 1837, Mondeux in 1840, Prolongeau in 1846, and Grandmange in 1852. Mangiamele ${ }^{3}$ and Mondeux ${ }^{4}$ in particular attracted great interest not only in their talents but also in the shapes of their skulls. Ten years after Gall's death in 1828, this research had sparked a revival of phrenology in France (Renneville, 2000).

Ultimately, this research would lead the Academy of Sciences (1892) to Jacques Inaudi (1867-1950), the study of whom had important theoretical implications for questions concerning the unity of memory, neuroanatomical localization of memory and calculation, and the heredity of expertise in memory and calculation. At different times, both Paul Broca (1824-1880) and Jean-Martin Charcot (1825-1893) studied Inaudi, though the two came

${ }^{2}$ As pointed out by Dehaene (1997), mental calculators had always intrigued scholars (see also Brown \& Deffenbacher, 1975, 1988). Such phenomenal individuals inspired fanciful explanations for example, some asserted that the mental calculators had received a "gift from god" — until Franz Josef Gall (1758-1828) made the first serious attempt at a scientific account. Gall believed that the power of mental calculation was due to an organ of "sense of the relationships between numbers" located in the frontal regions of the cortex (Gall, 1819, pp. 126-138). As mental faculties were deemed innate, mathematical talent could be detected from childhood by "craniometry." In 1814, Gall had the opportunity to study the mental abilities of the young calculator Zerah Colburn (for a biography, see Colburn, 1833).

${ }^{3}$ Exhibited as a "calculating boy," the young Sicilian shepherd Mangiamele (1827-?) appeared before the Academy of Sciences at the age of 10 (Arago, 1837). Although he was able to mentally calculate three-digit cube roots (e.g., the cube root of 3,796,416 is 156) and to perform several other complex arithmetical problems, he did not explain his methods. As he seemed even better at calculation than Zerah Colburn, phrenologists saw in him a chance to decisively verify the localization of the organ of numbers and calculation (Renneville, 2000). By making a mold of Mangiamele's skull and measuring its anomalous features, phrenologist Alexandre Dumoutier (1797-1871) claimed to have found just such a well-developed organ (Dumoutier, 1837). A fierce debate arose in the French medical newspapers between proponents of Dumoutier's view and scholars who questioned the quality of his observations. Physician François-Joseph-Victor Broussais (1772-1838), the de facto leader of the French phrenological movement after his delivery of a series of influential lectures (see Broussais, 1836), argued that if this cranial deformation was not substantial, Mangiamele's abilities did not depend only on his memory for numbers but also on other faculties (Broussais, 1837; see also Lélut, 1843, pp. 310-315).

${ }^{4}$ Though a prodigious mental calculator, Mangiamele was otherwise intellectually below average. Henri Mondeux (1826-1862), a young French boy from Tours with a wide forehead (Barbier, 1841, p. 54) and a talent for mental calculation, was similarly limited. The son of a poor woodcutter, Mondeux was illiterate. He amused himself by doing calculations while guarding his sheep, using clever methods of simplification of his own invention. In 1838, Jacoby, the director of a teaching institution in Tours, gave him a private education and then presented him, on November 16, 1840, to the Academy of Sciences in Paris. Mondeux was examined by a scientific committee that included François Arago (1786-1853), Etienne Serres (1786-1868), Jacques Sturm (1803-1855), Joseph Liouville (1809-1882), and Augustin Louis Cauchy (1789-1857). It was recognized that the child had an extraordinary talent for mental calculation and memory for numbers but not for any other type of information. In 1840, the committee published a report on some of the calculating processes Mondeux had invented (Cauchy, 1840). In it, Cauchy also described an experiment which the commissioners had performed on Mondeux. Mondeux had been asked to memorize a 24-digit number divided into four blocks and then to recite the six digits contained within each block. It took Mondeux five minutes to successfully complete this task. After his performance at the Academy of Sciences and his subsequent examination by two prominent French phrenologists, Fossati and Dumoutier (who claimed that Mondeux's calculation bump was well developed, thus "confirming" the phrenological hypothesis) (Jacoby, 1846, p. 148), Mondeux became very famous in France. However, he sank into oblivion as quickly as he had risen to celebrity. His calculating ability did not progress with age and it is possible that Mondeux suffered from an intellectual disability. 
to very different conclusions. Broca (1880) offered a new psychological hypothesis ${ }^{5}$ : The faculty for mental calculation is attributable not to a special organ, as had been proposed in the phrenological hypothesis, but more simply to extraordinary memory for numbers. He was also the first to identify the importance of memory in mental calculation, noting that Inaudi did not make use of visual images. ${ }^{6}$ Charcot (1892), by contrast, adopted the viewpoint of a neurologist, noting that Inaudi's skull was plagiocephalic and featured slight protrusions of the right frontal eminence and left parietal eminence. He sought to develop a psycho-physiological explanation for the Inaudi case but was hesitant to argue for the neuroanatomical localization of calculation and memory for numbers.

Despite its importance in the history of psychology and neuroscience, the story of the psychological and anthropological study of Inaudi has yet to be written in detail. In the following article, after providing some biographical information on Inaudi, we will present Binet and Charcot's approaches, as well as a survey of theories given by notable scholars of the time to explain the source of Inaudi's abilities.

\section{Young Jacques Inaudi Becomes as Famous as Henri Mondeux}

Though several short biographical studies of Inaudi exist (see Binet, 1894a; Smith, 1983), the most noteworthy is his autobiography (Inaudi, 1925), a rare document recently rediscovered by one of the authors of the present article in a Parisian bookshop (see Figure 1). Giacomo "Jacques" Inaudi, the third and youngest boy of his family, was born on October 13, 1867, in Roccabruna in the Piedmont region of northern Italy. Inaudi, whose mother died when he was five years old, first demonstrated his talent for figures when he began tending sheep in order to supplement his impoverished family's income. At six, while watching his flock, he took to combining numbers in his head. Inaudi used only mental and auditory representations of figures, recalling numbers by their names, a skill taught to him by his older brother. As neither Inaudi nor his brother knew how to read, he learned the names of the numbers up to 100 by ear. When he had exhausted all of the calculations that he could think to perform with this knowledge, he asked to be taught higher numbers so as to expand the scope of his mental operations. Thanks to continual practice and innate talent, the young calculator made rapid progress. Shortly thereafter, Inaudi abandoned his native Italy in order to travel to Provence, France, with his two brothers. The three became organ grinders and buskers, begging in the streets, playing a hand organ, and exhibiting a dancing marmot.

The brothers lived nomadically in the south of France for two years until, in Montpellier, seven-year-old Inaudi decided to leave his siblings. At Béziers, he astonished a farmer sitting outside a café trying to manage his accounts. Inaudi offered to help him and, to the farmer's surprise, succeeded without the use of pen or paper. It was during this period that Inaudi discovered his astonishing calculating abilities. Subsequently, his two brothers rejoined him and took Inaudi back to the Montpellier region. In Sète, a small town

${ }^{5}$ Gall's approach was first challenged by French philosopher Hippolyte Taine (1828-1893), who proposed that mental calculation was the result of great visual imagination (Taine, 1870).

${ }^{6}$ There exist two categories of mental calculators: (1) visual calculators, who mentally "see" numbers, and (2) auditory calculators, who mentally "hear" numbers. At the time, it was assumed that all mental calculators were of the visual type (Scripture, 1891; more recent analyses have assessed mental calculator Zerah Colburn to have been an auditory calculator; see Mitchell, 1907; Smith, 1983). However, Inaudi performed mental calculations by using the names of numbers. Further, most young mental calculators reified their computations. Mondeux, for instance, counted on pebbles and on his fingers as a child. Inaudi, however, did not give his calculations material form. 


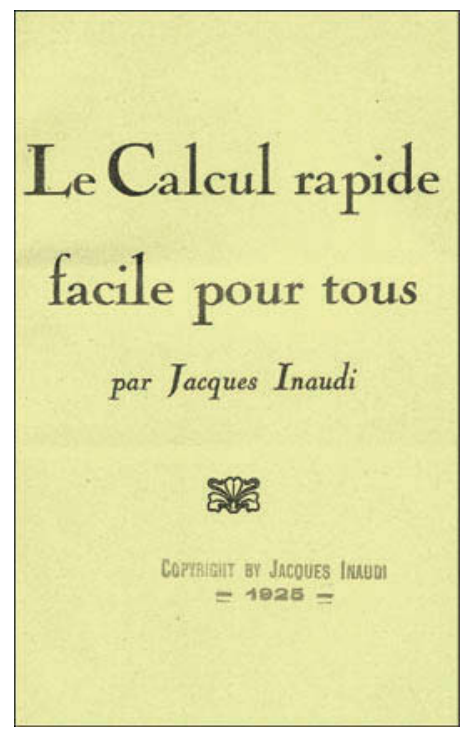

Figure 1. Jacques Inaudi's rare 1925 book, Le Calcul rapide facile pour tous (Rapid Mental Calculation for Everyone), which includes his biography and his methods of calculation (S. Nicolas, Private collection; color figure available online).

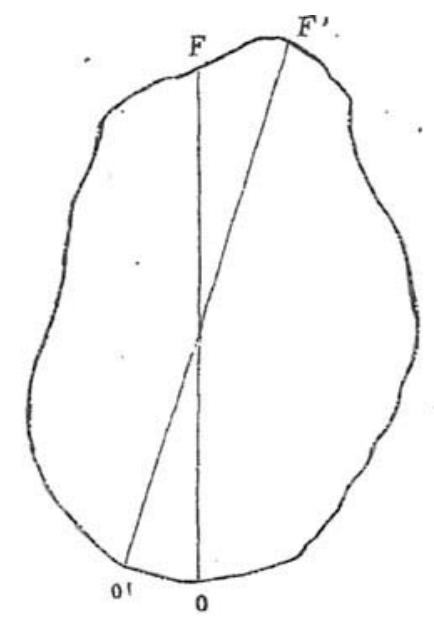

Figure 2. A sketch of the contour of the Inaudi's skull (January, 1879; age 12) by Amat (1880). Amat noted the two prominent frontal bumps, the right more developed than the left. The parietal eminences are also very pronounced, particularly on the left side $(\mathrm{O}=$ Occipital point and $\mathrm{F}=$ Frontal point $)$.

between Montpellier and Béziers, Inaudi stunned passers-by and customers alike by solving long and complicated arithmetical operations in his head. Observers were astonished to find that despite the child's sharp mind, he could neither read nor write. Louis Amat, who commented on Inaudi in 1880, was struck by the size and shape of his head. Inaudi's forehead, wide and high, had two prominent frontal bumps (see Figure 2).

In Marseille, Inaudi eventually found work shining shoes. There, he came up with the idea of entertaining customers sitting on the terraces of local cafés in order to draw their 
attention. His talent was a steady source of income for his brothers, who encouraged him to frequent the cafés and to exhibit his powers by performing tricks, including rapidly calculating the number of minutes that customers had lived from birth. Inaudi's reputation spread so widely that an enterprising barkeeper from Marseille hired his brother as a dishwasher and offered young Jacques a job as an attendant. The clientele of the café increased daily as customers specifically requested Inaudi; the café, with its calculator-attendant, had become an attraction in Marseille.

Inaudi was soon thought of alongside Mondeux, memory of whom was still very much alive in the public mind. Toussaint Samat (1841-1916), the founder and former director of the daily paper Le Petit Marseillais, published the first article on the "new Mondeux" (see George, 1880) on December 21, 1879:

A new Mondeux can now be seen at the Café du Louvre, near rue de Noailles, where customers question him tirelessly. There, you will find a ten-year-old Italian who does not know how to read or write, but is endowed with the wonderful gift of solving mentally, in a matter of seconds, the most difficult and complex calculation problems. Only yesterday we asked him to give us the product of the multiplication of 28,427 by 5,555 . The child walked around a table, tilted his head, and, less than thirty seconds later, loudly gave us the answer: $15,791,198$.

A customer told him his age and the young boy almost immediately gave him the corresponding number of days, hours, minutes and seconds.

He solved all of the arithmetical operations that were submitted to him with the same speed.

The child has his own mnemonic method, which he keeps secret. He claims to have discovered it unexpectedly at the age of 7 . The conformation of the skull of the young I . . ., is characteristic, and the proponents of Gall's system now have a good subject at their disposal upon whom to conduct experiments of compared phrenology. (Samat, 1879, p. 1)

Inaudi was 10 when Bénédict Jules Dombey, a représentant de commerce ${ }^{7}$ living in Lyon, approached Inaudi's father, still living in Italy, through Inaudi's brother. This agent had seen in Inaudi an opportunity for both of them to profit. Dombey secured Inaudi's father's signature on a contract giving him the right to capitalize on Inaudi's calculating abilities. In exchange, Inaudi's father received a monthly payment of 150 francs. Inaudi traveled with Dombey to Paris, performing in the cafés of French cities along the way. Upon their arrival in Paris, Dombey began contacting the editorial staffs of newspapers and presenting Inaudi to scientific societies. In 1880, the Société d'Anthropologie de Paris (Anthropological Society of Paris), directed by Paul Broca, invited the young mental calculator to a session.

\section{Broca Introduces Inaudi to the Anthropological Society of Paris (1880)}

Unlike some of his prestigious contemporaries in medicine, Broca (for a biography, see Schiller, 1972/1993) was never elected to the Academy of Sciences (Schiller, 1972/1993, p. 5). Nevertheless, Broca was a member of the Academy of Medicine and the founder

${ }^{7} \mathrm{~A}$ représentant de commerce is a kind of door-to-door salesman working under contract and generally on commission. 
of the famous Anthropological Society of Paris, of which he served as president for more than 20 years. Broca considered anthropology the natural science of man (Blankaert, 2009). The Anthropological Society of Paris, which aimed to collect data from fields as diverse as medicine and paleontology, prioritized human anatomical and physiological research. Broca believed that anatomy and craniology allowed researchers to approach human diversity in a scientific way. In the first discussions held at the Anthropological Society of Paris in the early 1860s, Broca (1861a) was able to present one of the most important discoveries of his scientific career: the cerebral localization (in the third left frontal convolution) of spoken language in the famous aphasic (aphemic) case Leborgne (Broca, 1861b). ${ }^{8}$ Twenty years later, another discussion at the Anthropological Society of Paris would lead Broca to investigate a new aspect of cerebral localization.

From its foundation in 1859, the Anthropological Society of Paris held discussions on a variety of topics. In February 1880, members of the Anthropological Society of Paris began to discuss the singular ability, possessed by only a few individuals, to perform very complicated mental calculations without the aid of written arithmetic. During the February 19, 1880 session of the Anthropological Society of Paris, Antoine Thomson d'Abbadie d'Arrast (1810-1897), a well-known scholar and explorer (see Darboux, 1907), presented a recently published work by Francis Galton (1822-1911) from the English review Nature (Galton, 1880). This early paper on visual memorization concerned the often-elaborate ways by which individuals possessed the ability to see images in the mind's eye. Galton cited George Parker Bidder (1806-1878), an eminent engineer who had displayed a talent for calculation from an early age. ${ }^{9}$ His son, George Parker Bidder, Jr. (1836-1896), inherited some of his marvelous talent. Bidder was able to mentally calculate the product of two 15-digit numbers, though not with his father's degree of speed and accuracy. Bidder, a visual calculator, wrote that he did not understand the possibility of mental calculation without visual representations of numbers: "When I calculate a sum mentally, it always proceeds in a visible form in my mind; indeed, I can conceive of no other possible way of doing mental arithmetic" (Bidder, 1878, p. 1634). This case, described by Galton (1880), was peculiar due to Bidder's unique way of mentally arranging arithmetical numerals. Bidder's memory of a numerical series was dependent upon a clear mental vision of each number's location in a mental diagram. Every number was given its own definite place in the series. For example, when he thought of the number "six," the figure " 6 " arose in his mind's eye more readily and vividly than the word "six" echoed in his mind's ear. He would assign to each number a definite place in his mental field of vision; they would then appear to him to fall into a pattern or "form." These forms were mnemonic diagrams. When Bidder multiplied two large numbers, he would shift his focus away from the place of each individual number.

These examples of psychological schemas monopolized the discussion during the February 19th session. Psychiatrist Louis Jean François Delasiauve (1804-1893) argued that this type of mental functioning supported Gall and Spurzheim's phrenological system insofar as capacity for calculation seemed to be independent of other mental faculties. The general disdain for phrenology, and in particular that of General Secretary of the Academy of Sciences Pierre Flourens (1794-1867; see Flourens, 1842, 1863) and General Secretary of the Academy of Medicine Frédéric Dubois d'Amiens (1797-1873; see Dubois d'Amiens, 1842), seemed to him to be misguided; he sought to defend it against its

\footnotetext{
${ }^{8}$ The details of this case and Broca's subsequent discovery have been discussed at length in numerous works (e.g., Finger, 2000).

${ }^{9}$ Bidder was probably an auditory calculator (see Bidder, 1856).
} 
detractors (Delasiauve, 1844). Gustave Le Bon (1841-1931) pointed out that psychologists, especially Hippolyte Taine (1828-1893) in his work on intelligence (Taine, 1870), had found that mental calculators reported using visual memory as the basis for their calculations. Speaking last, Broca asked d'Abadie to attempt to produce a written representation of mental calculators' visions of figures.

When Inaudi arrived in Paris in the winter of 1879-1880, Albert Lévy (1880) described the young boy:

He is a small lad, washed and groomed, sharp like a child who understands the crowds. He looks very mature, with lively and kind manners, but with the somewhat old-fashioned face of a child who aged too quickly; the precocity of his intelligence shows on his face. His forehead is shockingly large and when he concentrates his intelligence on a problem, he lays his head between his hands to think. One wonders if it is going to burst. (p. 224)

Others also noted the shape and disproportionate size of Inaudi's head compared to his height (see George, 1880). His forehead was high and domed and the frontal eminences were both prominent, though the right was much more so than the left. The parietal eminences were also pronounced, particularly on the left side, to such an extent that there seemed to be a certain degree of plagiocephaly. But this conformation cannot be attributed to hydrocephaly and seems rather to be due to cerebral hypertrophy. However, perhaps his most important characteristic, which Broca was to discover, was not observable to the naked eye: Inaudi's use of auditory memory.

Two days later, on February 21, 1880, Inaudi's representative came to Broca's home to introduce him to the remarkable 12-year-old (see Figure 3). Broca decided to present

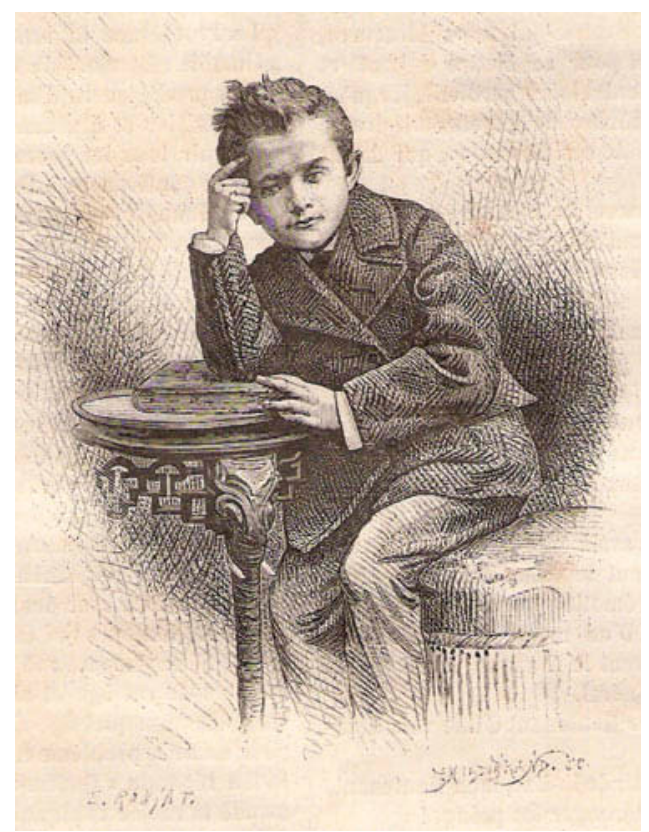

Figure 3. Twelve-year-old Inaudi (Levy, 1880, vol. 16, p. 224). (S. Nicolas, Private collection; color figure available online). 
Inaudi at the Anthropological Society of Paris shortly thereafter. Galton had argued that all calculators were visual types, but Broca was able to demonstrate that Inaudi was an exception. Broca examined Inaudi during a session of the Anthropological Society of Paris on March 4, 1880. He reported the calculations that the young Inaudi performed, indicated the time taken to solve the problems posed to him and even attempted to explain the techniques that Inaudi employed. Inaudi's operations included addition, subtraction, multiplication, division, and the calculation of roots. Broca noted that Inaudi was very intelligent with a lively gaze and animated features. However, his mental calculations, extraordinary though they were, took much more time than they would ordinarily take using a pencil and paper. Analyzing Inaudi's techniques, he observed, "He knows neither how to read nor write. He keeps track of numbers in his head but he does not write them down" (Broca, 1880, p. 245).

The basis of all of Inaudi's calculations was multiplication. Even when division and root extraction were required, he multiplied. In division, for instance, he found the quotient by grouping numbers and seeking the number that, multiplied by the divisor, would equal the dividend. Broca compared these successive groupings to seeking words in the dictionary. For example, during the session, Broca was easily able to uncover the procedure that Inaudi used to extract square roots, essentially a process of trial and error. Although Inaudi did not know the square roots of all numbers, he did have mental markers that allowed him to recognize quickly that the square root of a number must fall between certain limits. Then, using his extraordinary capacity for mental multiplication, he would square each number within those boundaries. In brief, Inaudi's faculty for calculation relied entirely upon his use of an empirical multiplication technique made possible by his prodigious memory for numbers. Noticing this, Broca was the first to emphasize the importance of memory in mental calculation. He did not attribute extraordinary faculty for mental calculation to cerebral hypertrophy (the phrenological hypothesis) or psychological schema (Taine's hypothesis) but instead to memory. Contrary to Taine's 1870 theory, Inaudi did not picture the numbers that he combined in his head because he used only the names of those numbers. Visual memory was not the basis of his mental operations. However, Broca did not have time to develop his ideas on this subject because he soon took on a new challenge: representing science in the Senate. Broca was elected Senator on February 5, 1880, supported by the party of the Republican Union, the governmental coalition. He died only five months later of a brain aneurism.

The story of Inaudi's scientific importance did not end with Broca's death. The astronomer Nicolas Camille Flammarion (1842-1925), who had developed an amateur interest in mental calculators, heard about Inaudi's performance at the Anthropological Society of Paris and decided to present him to friends at a party at his home on April 8, 1880 (Bouillac, 1880). As Le Monde Illustré reported on April 24, 1880, "We perched him on a table. Flammarion asked him, 'About one child is born every second; how many births does that come to in a century?' After two minutes, the child answered, '3,153,600,000.' However, the result obtained beforehand by abacus did not match Inaudi's answer. Somebody then asked Jacques, 'Did you count leap years?' He responded, 'Do you want leap years? Then it is 3,155,760,000 births"' (J. D., 1880, p. 260). Inaudi proved capable of answering complex arithmetical problems without visible fatigue and without being distracted by the amusements in the room, no small task for a child of his age. Flammarion soon presented him to the public in the concert hall of the Capucine, where he gave popular talks on astronomy (Flammarion, 1880). Inaudi also performed at the Robert Houdin Theater and the Folies Bergères in June. Taking advantage of his success with the public, he began a European tour. For several years, he traveled through cities in France, Switzerland, and Belgium, where many hoped to stump the young boy by posing questions 
that they believed would be too difficult for him. Inaudi performed anywhere where one could address and amaze an audience, including music halls, theaters, cabarets, and meeting rooms. In the 1880s, as a result of his performances, Inaudi's fame increased among the European public.

\section{Inaudi at the Academy of Sciences (1892): Charcot's Report}

In the late 1880s, a number of elements contributed to Inaudi's reintroduction to mathematicians and psychologists. First, as Inaudi's talent for calculation improved (Baudouin, 1892), he captured the attention of scholars at a time when more and more articles on mathematical prodigies were appearing in newspapers (e.g., Scripture, 1891). Second, because Broca had not described many of Inaudi's methods, his calculations were still enigmatic. Finally, his abilities were based on auditory memory. Ribot (1881) was the first to point out the existence of multiple types of memory in his influential book on the subject. He demonstrated that language pathologies could provide information about the workings of memory. Charcot, who became interested in Ribot's work, began to search for the cerebral bases of language and memory in the 1880s. These two faculties were linked in the minds of contemporary scholars because language pathology was widely believed to be a type of memory pathology (cf., Gasser, 1995, p. 143). Charcot believed that aphasia was the failure of a psychological function, language, acquired through memory, as language consisted of the implementation of the memory of signs. Consequently, for Charcot, the loss of language involved a kind of amnesia of signs. His proposed model of aphasia based on the existence of multiple types of verbal memory (i.e., auditory, visual, and motor) attracted much attention in the scientific community. According to Charcot, when a certain type of verbal memory is affected, a corresponding form of aphasia occurs. Conversely, when a certain type of verbal memory (e.g., auditory memory) is overdeveloped, a corresponding form of hypermnesia occurs. In his examination of Inaudi, Charcot believed that he had discovered evidence to support this theory.

\section{Existence of Different Types of Memory: Charcot's Model}

Charcot (for a biography, see Goetz, Bonduelle, \& Gelfand, 1995) was the first to find, between 1861 and 1863, several patients who confirmed the principle of localization of spoken language described by Broca. Increasingly, speech pathologies became topics of research in France and abroad, with major contributions from Hughlings Jackson (1864), Henry Bastian (1869), Carl Wernicke (1874), and Adolph Kussmaul (1877), among others. During the summer of 1883, influenced by these contributions, Charcot gave a series of lectures on the forms of aphasia, basing his theory on the existence of four independent types of aphasia (also considered partial or local amnesias by Charcot, 1890, p. 517) localized in different areas of the brain (Charcot, 1883a, 1884, 1885; see also Gasser, 1995, p. 188): (1) word blindness, verbal amnesia in the visual domain localized in the inferior parietal lobule; (2) motor aphasia, verbal amnesia caused by deficits in motor articulation localized in the third frontal convolution; (3) agraphia, verbal amnesia caused by deficits in symbolic representation (graphism) localized in the second frontal convolution; (4) and verbal deafness, verbal amnesia in the auditory domain localized in the first temporal convolution.

Charcot named each of the four "centers" of the structure of memory for language in a graph representing his study of aphasia (see Figure 4; Charcot, 1884; see Gasser, 1995, 


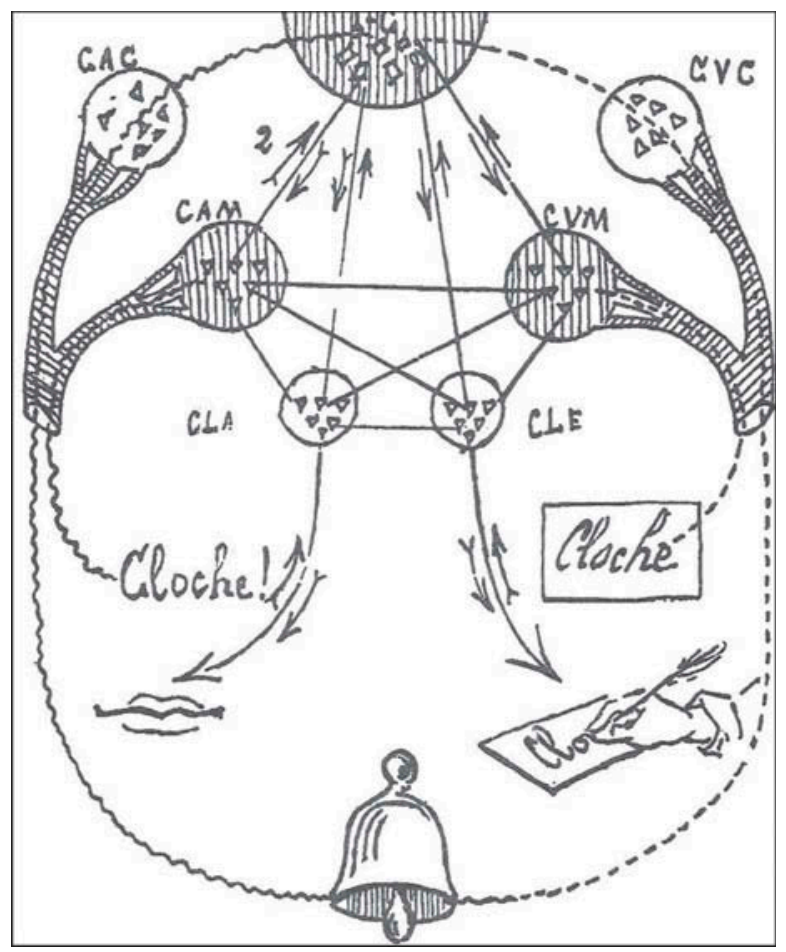

Figure 4. Charcot's model of aphasia, commonly known as the "Charcot's Bell" diagram (see Ballet, 1886, p. 7).

p. 152). In it, four circles are drawn, one in each corner of a small rectangle, representing the four forms of the disease. Charcot portrayed the organs visually in order to show their relationships: The eye is connected with the center of visual memory (CVM, Centre Visuel des Mots), the ear with the center of auditory memory (CAM, Centre Auditif des Mots), the hand with the center of writing (CLE, Centre du Langage Écrit), and the mouth with the center of spoken language (CLA, Centre du Langage Articulé). A fifth circle above the rectangle represents the general center of ideas (IC, Ideation Commun). To represent language as a function, Charcot sought to show the many links connecting the four centers with one another and with the IC, which Charcot did not believe to be localized. In the case of reading, after visualizing words, one could pronounce them or write them. Two further centers must be added to those five original centers and linked with the CAM and CVM: (1) the general auditory center (CAC, Centre Auditif Commun) and (2) the general visual center (CVC, Centre Visuel Commun). This somewhat complicated arrangement would be helpful in providing a clearer understanding of this subject.

Charcot's model of aphasia is based on the model of multiple memories put forth by Ribot, who wrote that "memory may be resolved into memories" (Ribot, 1881, p. 107). Psychologists before Ribot either neglected or denied this hypothesis (see Charcot, 1883b). Charcot reasoned that, because the function of language is composed of a certain number of independent mental operations and because these operations allow us to acquire memories, every individual has four unique kinds of memory: one for reading, one for writing, one for understanding spoken words, and one for speaking. It was believed that these kinds of verbal memory were distinguishable by the nature of the images evoked. Suppose that the 
word "bell" is spoken. What effect will this word have upon the hearer's mind? If such a person relies more on visual memory, one will form a mental image of the bell as an object, complete with shape and color. But if the nature of the memory is auditory, the idea of a bell will connect itself with the sound of a bell. A third possibility, undoubtedly much rarer than the previous two, is that the word "bell" may evoke a mental representation of the sensations experienced by touching a bell with the hand. A fourth possibility is that one might experience some combination of these types of memory.

In brief, the four types of memory hypothesized by Charcot (1885) are the following: (1) visual memory, characterized by the use of visual images (painters, for instance, rely on visual memory when they draw a person's portrait after having seen that person only once); (2) auditory memory, which involves special use of memory for sounds, as might occur with a musician; (3) motor memory, wherein images derived from the physical world (i.e., touch or tactile sensations) are evoked; and (4) indeterminate memory, wherein more than one type of image is used. Since each individual has his or her own method of remembering, thinking, reasoning, etc., individuality results in part from the prevalence of certain types of memory over others. Common experience demonstrates the disproportionate use of different types of memory by different individuals. Ribot (1881) made reference to some calculators, such as Zerah Colburn, who could mentally "see" figures before their eyes, and other calculators, like Inaudi, who "heard" them: "In the same person, then, an unequal development of the different senses and different organs induces unequal modifications in the corresponding portions of the nervous system, hence unequal conditions of recollection and, ultimately, varieties of memory. It is even probable that inequality of memory in the same person is the rule rather than the exception" (Ribot, 1881, p. 140). In 1892, when Darboux brought Inaudi before the Academy of Sciences, Charcot had the opportunity to observe a very peculiar case of auditory memory.

\section{Inaudi's Examination by Charcot at the Salpêtrière Hospital}

Between 1880 and 1892, Inaudi had made great progress. Not only did he learn to read and write but his mental calculations proved remarkably accurate for the complexity of the problems that he solved and the speed with which he solved them. Inaudi's fame became so great in France that Gaston Darboux (1842-1917) presented him at a session of the Academy of Sciences on February 8, 1892. Inaudi's new impresario, the prestidigitator "de Thorcey," whose real name was Albert Ferdinand Guyot, helped to organize the presentation. At the beginning of the session, Darboux reminded the audience that in 1840, another prodigious calculator endowed with similar faculties, Henri Mondeux, had been studied by the Academy of Sciences. He then asked Inaudi to perform multiple arithmetic operations, for example to mentally subtract the number $1,248,126,138,234,128,910$ from the number 4,123,547,238,445,523,831 (cf., Flammarion, 1892). Henri Poincaré (1854-1912) proposed a complex arithmetical problem and, at the same time, Joseph Bertrand (1822-1900) posed the following question: "What day of the week was March 11, 1822?" (It was a Monday.) Inaudi answered both questions immediately.

Impressed by Inaudi's performance, the Academy of Sciences convened a committee to examine the psychological basis of Inaudi's mathematical techniques. Darboux was charged with producing an overview of Inaudi's techniques while Charcot was tasked with the study of Inaudi's memory. Charcot examined Inaudi at the Salpêtrière hospital on February 27, March 1, and March 3, 1892 (Archives Charcot, n.d.). Seeking to compare Inaudi to Mondeux, Charcot re-created the experiment described in detail by Cauchy in his 
report on Mondeux. It consisted of asking Inaudi to memorize a 24-digit number divided into four groups and to recite the six digits contained in each group. While Mondeux took five minutes to accomplish this, Inaudi needed only seconds. For instance, Inaudi was given the following digits: 379131, 453786, 492167, and 299854. Inaudi repeated each block, then the first block in reverse order, and finally the entire number in reverse order beginning with the final digit, all in 59 seconds. Charcot noted that Inaudi's talents extended only to memory for figures. His memory for other items was average or below average. Charcot also confirmed that Inaudi was an auditory mental calculator by performing an ingenious test. Inaudi was asked to memorize five numbers, each of five digits, written in a block on a sheet of paper. Then he was asked to recite from memory either diagonal, vertical, or horizontal sequences in the numbers. He succeeded, but with difficulty. If Inaudi had been a visual calculator, he would not have struggled, as he would have "read" the answers as though they were laid out before him on an imaginary blackboard.

During these sessions, Charcot examined Inaudi primarily from the psychophysiological and anthropometric perspectives, leaving to his former collaborator Alfred Binet (1857-1911) the psychological study of Inaudi (see Binet, 1894a). Charcot believed that Inaudi's abnormal talent was hereditary. According to Charcot, since Inaudi's father did not have a similarly extraordinary memory for figures, and such talents were inherited paternally, Inaudi's memory for numbers and arithmetic must have been transmitted to him indirectly. This abnormality was physical as well. Inaudi was a small man at $1 \mathrm{~m} 52$ (approximately five feet tall) with a plagiocephalic skull. Thus, it appeared to Charcot that calculation or memory for numbers, or both, might involve the right frontal and left parietal regions.

\section{Darboux and Charcot's Final Reports on Inaudi's Memory (1892)}

Charcot and Darboux's reports were published in the Comptes-Rendus Hebdomadaires des Séances de l'Académie des Sciences on June 7, 1892 (Charcot, 1892; Darboux, 1892). Charcot's report, which raised great scientific interest, was to be reprinted in several scientific journals. The report was based on his own observations, as well as experiments conducted by Binet at the Sorbonne laboratory (see Nicolas \& Sanitioso, 2012).

Darboux (1892), who studied Inaudi's mathematical techniques, found that he relied primarily on his prodigious memory. For instance, Inaudi could quickly perform multiplication with factors containing over six digits; it took him less than 10 seconds to find the cube of 27. Darboux also pointed out a fact that had been overlooked:

The calculator himself conceived of these techniques. They are entirely original. Whereas Mondeux and many other prodigies had received instruction from men who transmitted the usual methods to them, Inaudi, never having had a teacher, surely conceived of the rules that he applies to each of his operations himself. What is interesting is that although these rules differ from those taught in primary schools throughout Europe, a few of them resemble those followed by other peoples, such as the Hindus, in certain respects. (Darboux, 1892, p. 1336)

When adding or subtracting, Inaudi began with the leftmost digit rather than the rightmost. When multiplying, he followed a method based on his memory. He would split a 
complex multiplication problem into a series of simpler calculations. If asked to multiply the number 325 by the number 638 , his calculations would be:

$$
\begin{aligned}
& 300 \times 600=180,000 \\
& 25 \times 600=15,000 \\
& 300 \times 30=9,000 \\
& 300 \times 8=2,400 \\
& 25 \times 30=750 \\
& 25 \times 8=200
\end{aligned}
$$

Inaudi performed six multiplications instead of one, beginning with the larger numbers. In other cases, he completely altered the problem given to him. For instance, instead of multiplying by 587, he would multiply by 600 and then by 13, then subtract the second product from the first. When performing division, Inaudi followed the ordinary rule by reducing division to subtraction. As Broca (1880) had already noted, when calculating a number's roots, he followed no particular rule, relying instead on trial and error. Darboux ended his report with the remark, "Given that many celebrated mathematicians have shown mnemonic gifts similar to his, it is regrettable that he did not receive any lessons from an intelligent and capable master at an age when he could enter into studies (Darboux, 1892, p. 1338).

For Charcot (1892), the types of memory were unique but potentially interrelated. In "abnormal" functioning, one type of memory could weaken (amnesia) or develop disproportionately (hypermnesia) without affecting any other type of memory. In Inaudi's case, of course, memory for figures and numbers alone was remarkable. To understand the extent of Inaudi's memory for figures, Charcot compared it to his memory for other types of information. He did this by reciting a series of letters, asking Inaudi to repeat them accurately and then doing the same with digits. Faced with numbers, Inaudi could repeat 25 to 30 digits effortlessly. He could reproduce series at will, either in the order in which they were spoken or in reverse order, and he could even recall the digits after several weeks. But this was not at all the case with letters. Charcot observed that Inaudi was unable to repeat more than five or six letters from memory. According to Charcot, "He hesitates, loses his usual confidence, and wants to stop the experiment" (1892, p. 1332). He was not able to reproduce two lines of French word-for-word after a single hearing. Inaudi's memory for other materials (colors, forms, events, places, etc.) did not surpass the normal range and was even below average in some respects. Charcot pointed out that in terms of memory, Inaudi was surpassed by none of the calculators who preceded him.

As Charcot realized, the development of Inaudi's auditory memory was both considerable and abnormal (see Richet, 1892). Consulting Scripture's 1891 article on arithmetical prodigies and mental calculators, Charcot found that those individuals reported using visual memory as the basis of their mental operations, as Taine had suggested earlier (1870). These mental calculators would see internal visions of the numbers contained in mathematical problems. Mondeux and many others who elaborated on their techniques employed this method of visualization (Scripture, 1891). Inaudi, by contrast, heard his figures as though they were being whispered into his ear. It had been thought impossible, prior to the Inaudi case, that mental calculations of such difficulty could be carried out solely by means of auditory memory. However, his testimony, as well as the posture that he adopted as he calculated and the various tests to which he was submitted, left no room for doubt. When the commission questioned him closely on the issue, Inaudi affirmed without hesitation that he "saw" no visible representation of figures at all: "I hear the figures and it is my ear which 
retains them. As I attempt to reproduce them from memory, I hear them resonate within me, in the tone of my own voice, and I continue to hear them throughout a great portion of the day. In an hour, two hours, if I want to think of the number that has just been spoken, I will be able to repeat it just as accurately as I did moments ago" (Charcot, 1892, p. 1333). Indeed, Inaudi had much more difficulty remembering numbers when they were given to him in writing than when they were spoken. Neither did he like to write the figures himself; the writing did not help him at all to recall them.

Charcot was also interested in Inaudi's anatomical peculiarities. He subjected Inaudi to a number of anthropometric investigations (Carson, 1999), including analyses of Inaudi's cranial features and various skull measurements. In his report, Charcot noted that "The skull is markedly plagiocephalic, and presents in front a slight protrusion of the right frontal eminence, and behind, a protrusion of the left parietal eminence; a longitudinal crest of $0.02 \mathrm{~m}$, formed by a protrusion of the right parietal is perceptible to the touch in the posterior part of the interparietal suture" (Charcot, 1892, p. 1330). But when Baudouin (1892) asked Charcot about the localization of these memories, he answered, "the moment has not yet come to formulate a hypothesis" (Baudouin, 1892, p. 64). Charcot was wary of accidentally reinstating Gall's phrenology in France. In an unpublished manuscript he added:

Thus, we can divide arithmetical prodigies into two classes: visual prodigies [les visuels] and auditory prodigies [les auditifs], and it is not impossible that in the future the categories of spoken motor prodigies [les moteurs d'articulation] and writing motor prodigies [les moteurs graphiques] will be revealed. Figures, just like words, possess four fundamental elements, that is to say, a complete external language. Yet for figures, as for words, external language is only the reproduction of visual, auditory and motor mental images, that is to say, the echo of the inner language of figures in its four forms. This is only a purely theoretical view. The observation of Inaudi and other arithmetical prodigies provides conclusive evidence, and pathology could one day well offer us an isolated example of aphasia for numbers, blindness or deafness for figures. (Archives Charcot, n.d., Inaudi, pp. 21-22)

By "spoken motor prodigies" and "writing motor prodigies," Charcot meant calculators whose abilities were based on the articulation or writing of words. Although Charcot did not publish a diagrammatic model for numbers and digits, he did publish the "Charcot's Bell" diagram to conceptualize language processes and deficits and speculated about parallel processes and deficits for digits and numbers. Thus, he concluded, there are distinct visual, auditory, and motor memories for numbers.

\section{Conclusion}

The first scientists to show an interest in mental calculators (e.g., the mental calculators Colburn, Mangiamele, and Mondeux) were phrenologists who believed that there existed a special organ for calculation to be found in the frontal regions of the cortex. In the 1840s, phrenology had been largely rejected in serious scientific circles, and French phrenology was relegated to the ranks of pseudo-science. Observing Inaudi in 1880, Broca eschewed the phrenological claims made by these earlier thinkers. Twelve years later, Charcot acknowledged Inaudi's incredible auditory memory but was cautious about cerebral localization of memory for digits and numbers. Yet, Inaudi was the first 
auditory calculator to have been studied scientifically, with Broca and Charcot's analyses of Inaudi's memory constituting the first psychological study of mental calculators. Moreover, for Binet, a former assistant of Charcot, exceptional memory for numbers was not the result of anatomical peculiarity, but rather "a combination of mental faculties, attention, will, perseverance, and above all a passion for studies associated with this memory" (Binet, 1894a, p. 44; see also Binet, 1892, 1893; Binet \& Henneguy, 1892).

Charcot's research on memory and his study of Inaudi touched upon a number of topics that are still relevant. In an unpublished manuscript from 1892, Charcot wrote that the "existence of multiple memories is today incontestable ... [it is] a psychological axiom" (Archives Charcot, n.d., Inaudi, p. 1). The scientific study of Inaudi's abilities demonstrated both the need to approach memory not as a whole but as a collection of components (for recent theoretical conceptions, see Squire, 1987, 2004, 2009; Tulving, 1983, 1995, 2007) and the importance of studying individuals with one exceptional type of memory in order to understand the mechanisms of normal memory. Calculators may be classified according to the way that they represent numbers mentally: there are those who "see" numbers in the mind's eye and those who "hear" them (see Smith, 1988). According to Charcot's model, Inaudi's auditory memory was extraordinarily developed but limited to numbers. Charcot theorized distinct visual, auditory, and motor types of memory. Smith $(1983,1988)$ has argued that auditory calculators like Inaudi, unlike visual calculators, had certain common features. They all exhibited some form of verbalization while calculating, they all employed self-taught, left-to-right methods of calculation, and they all learned how to calculate before learning written numbers. Today, the popular distinction between visual memory and auditory memory has led to the "learning style" approach to education, wherein individuals are classified into purportedly distinct groups (visual type vs. auditory type). Learning is supposedly more efficient if the learning style of students is taken into account. ${ }^{10}$

In his 1892 report on Inaudi, Charcot noted that the anatomy of Inaudi's brain was within normal limits with the exception of the protrusions in the right frontal eminence and left parietal eminence of his skull. Charcot refused to claim the existence of a correlation between mental calculation and specific anatomical characteristics of the brain, but it is notable that anthropological measures of Inaudi are consistent with the themes of modern cognitive neuroscience. Recent neuroimaging studies of mental calculation and number processing seem to show the activation of a network involving frontal and parietal structures (see Jost et al., 2011; Menon et al., 2000; Rickard et al., 2000). Whereas activation in the frontal cortex has been attributed mainly to working memory and the demands of attention during calculation, the activation of parietal areas may be directly associated with numberrelated processes (Jost et al., 2011). It has been suggested that distinct circuits mediate specific subcomponents of number processing within the parietal cortex (Dehaene et al., 2003). Thus, Charcot's research seems to have anticipated actual localization of mental calculation and memory for digits and numbers, though in ways that he could not have imagined.

Scientific studies of Inaudi also raised the issue of whether exceptional memory was a natural talent or one that could be developed through practice. Although Inaudi was not able to fully elaborate on many of the techniques that he used (though he seemed to employ a strategy of "chunking" into three digits), unlike some mnemonists (see Binet \& Henri, 1893), one can infer that he accumulated large sets of memorized data. Some authors have

\footnotetext{
${ }^{10}$ However, some studies (see Constandiniou \& Baker, 2002) have failed to establish a relationship between learning style (Richardson, 1977) and the verbal memory performance in a free-recall task. For a review, see Pashler, McDaniel, Rohrer, and Bjork, 2009.
} 
argued for the natural superiority of certain individuals with regards to mental calculation (e.g., Wilding \& Valentine, 1997, 2006). Since expert calculators frequently exhibit short-term memory for digit spans exceeding the average of $7 \pm 2$ digits (Miller, 1956), it has also been argued that mental calculators' exceptional performance may be due to extraordinary natural short-term memory capacity (see Hunter, 1977). For example, with a presentation rate of about two seconds per digit, Inaudi could report 36 digits. However, extended practice enables normal subjects to increase working memory span beyond $7 \pm 2$ digits (Ericsson \& Kintsch, 1995). ${ }^{11}$ Staszewski (1988) argues that experts are made, not born, as motivation and knowledge acquired through extensive and consistent practice are the essential components of prodigious memory. Moreover, in contrast to the work of Wilding and Valentine (1997, 2006), recent evidence suggests that no superior basic memory capacity is to be found in mnemonists (see Hu et al., 2009), and that superior memory performance may not be an innate talent. Further, it has been claimed that there is no evidence that talent for mental calculation is inherited (Ericsson, 2003; Ericsson \& Kintsch, 1995), contrary to Charcot's hypothesis. From a physiological perspective, Guida et al. (2012) showed that learning coincides with cerebral functional reorganization. From a modern neurological standpoint, "natural capacity" is seen as the result of functional and structural changes in the brain during training. For example, Pesenti et al. (2001) found that calculation expertise was not due to improved activity in processes that exist in nonexperts but instead results from the use of different areas of the brain for calculation (the right prefrontal and medial temporal areas). More precisely, cerebral functional reorganization involving long-term memory areas occurs with the development of expertise. ${ }^{12}$

The study of Inaudi's calculating abilities opened the door for new research and the many studies of calculating prodigies that have since been performed. Binet was the first to study another mental calculator, Périclès Diamandi (1868-?; Binet, 1894a, 1894b; Charcot \& Binet, 1893, see Nicolas, Gounden, \& Levine, 2011), and many scholars in France before World War I took up the study of mental calculators, including Urania Diamandi (1887-?), the sister of Périclès Diamandi (Ioteyko, 1910; Lahy, 1913; Manouvrier, 1908). But it was German psychologist Georg Elias Müller who conducted the most extensive research on a mental calculator, professor of mathematics Gottfried Rückle (1879-1929; Müller, 1911, 1917; see Murray \& Bandomir, 2000). More recently, Pesenti et al. (1999) have described the exceptional calculating abilities of Rüdiger Gamm. Gamm was observed performing single- and multidigit number multiplication, numerical comparison, exponential multiplication, and short-term memory tasks. This study revealed, like that of Inaudi, the importance of memory storage in Gamm's calculations.

\footnotetext{
${ }^{11}$ This improved performance is possible when we exploit long-term memory to expand working memory capacity. According to Ericsson (1985, 1988; Ericsson \& Kintsch, 1995), three principles characterize the cognitive processes underlying exceptional memory performance: (1) the meaningful encoding principle, which states that, to be easily stored in long-term memory, incoming information must be transformed into meaningful units; (2) the retrieval structure principle, which states that subjects must associate encoded information with a retrieval structure (in order to retrieve the encoded information, the expert must reinstate the encoding conditions by using the same set of retrieval cues); and (3) the speed-up principle, which states that with extensive practice, experts can speed up the encoding and retrieval of information in long-term memory.

${ }^{12}$ Cerebral functional reorganization does not simply mean that experts perform the same mental operations as novices but use different parts of the brain. Rather, it means that experts perform the required tasks differently. They execute short-term memory tasks using different mental operations based on long-term memory and its associated areas of the brain. A recent review of the neuroimaging literature by Guida et al. (2012) suggests that this may indeed be the case.
} 
Inaudi's talent for calculation did not weaken with time (Ioteyko \& Kipiani, 1908). Throughout his life, Inaudi competed against and consistently outperformed calculating devices in France and the United States (Dissard, 1947; Tocquet, 1957). He continued to perform in music halls until 1934. In 1937, he retired to Champigny-sur-Marne, near Paris, where he died on November 25, 1950. However, Inaudi's legacy, in the form of intensive psychological study of mental calculators and continued research on topics that his participation helped to develop, continues today.

\section{References}

Amat L (1880): Calcul mental et conformation crânienne. Revue Scientifique de la France et de l'Etranger 26: 29-32.

Arago F (1837): Mangiamele. Comptes Rendus Hebdomadaires des Séances de l'Académie des Sciences 4: 978-979.

Archives Charcot (n.d.): Inaudi, MA VIII 12 3.6, box 59.

Ballet G (1886): Le langage intérieur et les diverses formes de l'aphasie. Paris, Alcan.

Barbier H (1841): Vie de Henri Mondeux, jeune pâtre mathématicien. Paris, Appert.

Bastian HC (1869): On the various forms of loss of speech in cerebral disease. British and Foreign Medical and Chirurgical Review 43: 209-236, 470-492.

Baudouin M (1892): Le calculateur Jacques Inaudi. La Semaine Médicale 12: 62-65.

Bidder GP (1856): On mental calculation. Minutes of Proceedings, Institution of Civil Engineers 15: 251-280.

Bidder GP (1878, December 28): Letter. Spectator, 1634-1635.

Binet A (1892): Le calculateur Jacques Inaudi. Revue des Deux Mondes 111: 905-924.

Binet A (1893): Notes complémentaires sur M. Jacques Inaudi. Revue Philosophique de la France et de l'Etranger 35: 106-112.

Binet A (1894a): Psychologie des grands calculateurs et joueurs d'échecs. Paris, Hachette.

Binet A (1894b): Expériences sur M. Périclès Diamandi, calculateur mental. Revue Philosophique de la France et de l'Etranger 37: 113-114.

Binet A, Henneguy F (1892): Observations et expériences sur le calculateur J. Inaudi. Revue Philosophique de la France et de l'Etranger 34: 204-220.

Binet A, Henri V (1893): La simulation de la mémoire des chiffres. Revue Scientifique 51: $711-722$.

Blankaert C (2009): De la race à l'évolution: Paul Broca et l'anthropologie française (1850-1900). Paris, L'Harmattan.

Bouillac M (1880): Jacques Inaudi, le calculateur de dix ans. Revue Spirite 23: 192-194.

Broca P (1861a): Sur le volume et la forme du cerveau, suivant les individus et suivant les races (séances du 21 mars et 2 mai). Bulletins de la Société d'Anthropologie de Paris 2: 139-204, 308-321.

Broca P (1861b): Perte de la parole, ramollissement chronique et destruction partielle du lobe antérieur gauche du cerveau. Bulletins de la Société d'Anthropologie de Paris 2: 235-238.

Broca P (1880): Sur un enfant illétré, nommé Jacques Inaudi, doué de la faculté de faire des calculs très compliqués. Bulletins de la Société d'Anthropologie de Paris 3: 244-249.

Broussais FJV (1836): Cours de phrénologie. Paris, Baillière.

Broussais FJV (1837): Réfutation des opinions publiées par divers journaux à propos de Vito Mangiamele. La Phrénologie 1: 4.

Brown E, Deffenbacher K (1975): Forgotten mnemonists. Journal of the History of the Behavioral Sciences 11: 342-349.

Brown E, Deffenbacher K (1988): Superior memory performance and mnemonic encoding. In: Obler LK, Fein D, eds., The Exceptional Brain: The Neuropsychology of Talent and Special Abilities. New York, Guilford Press, pp. 191-211. 
Carson J (1999): Minding matter/mattering mind: Knowledge and the subject in nineteenth-century psychology. Studies in History and Philosophy of Biological and Biomedical Sciences 30: 345-376.

Cauchy A (1840): Rapport sur les procédés de calcul imaginés et mis en pratique par un jeune pâtre de la Touraine. Comptes rendus Hebdomadaires des Séances de l'Académie des Sciences 6: 952-957.

Charcot JM (1883a): De l'aphasie (cécité verbale, surdité verbale, aphasie motrice, agraphie). Revue Médicale 3: 693-702.

Charcot JM (1883b): Sur un cas de suppression brusque et isolée de la vision mentale des signes et des objets (formes et couleurs). Le Progrès Médical 11: 568-571.

Charcot JM (1884): Differenti forme d'afasia. Lezioni fatte nella Salpêtrière nel semestre d'estate dell'anno 1883, redate col consenso dell'autore dal dottore G. Rummo. Milano, Vallardi.

Charcot JM (1885): Lezioni cliniche dell' anno scolastico 1883-84 sulle malattie del sistema nervoso, redatte dal dottore Domenico Miliotti. Milano, Vallardi.

Charcot JM (1890): Oeuvres complètes (Vol. III). Paris, Lecrosnier \& Babé.

Charcot JM (1892): Rapport de la commission chargée de l'examen du calculateur Inaudi. ComptesRendus Hebdomadaires des Séances de l'Académie des Sciences 114: 1329-1335.

Charcot JM, Binet A (1893): Un calculateur de type visuel. Revue Philosophique de la France et de l'Etranger 35: 590-594.

Colburn Z (1833): A memoir of Zerah Colburn: Written by himself. Springfield, Merriam.

Constandiniou F, Baker S (2002): Stimulus modality and verbal learning performance in normal aging. Brain \& Language 82: 296-311.

Darboux G (1892): Rapport de la commission chargée de l'examen du calculateur Inaudi. ComptesRendus Hebdomadaires des Séances de l'Académie des Sciences 114: 1335-1337.

Darboux G (1907): Notice historique sur Antoine d'Abbadie. Paris, Gauthier-Villars.

Dehaene S (1997): The number sense. New York, Oxford University Press.

Dehaene S, Piazza M, Pinel P, Cohen L (2003): Three parietal circuits for number processing. Cognitive Neuropsychology 20: 487-506.

Delasiauve L (1844): Examen de diverses critiques adressées à la phrénologie. Paris, Cosson.

Dissard J (1947): Visite au génie: Inaudi a 80 ans. Journal des voyages 70: 1713.

Dubois d'Amiens F (1842): Examen des doctrines de Cabanis, Gall et Broussais. Paris, Cousin.

Dumoutier A (1837): Le jeune Vito Mangiamele. La Phrénologie 1: 3.

Ericsson KA (1985): Memory skill. Canadian Journal of Psychology 39: 188-231.

Ericsson KA (1988): Analysis of memory performance in terms of memory skill. In: Sternberg RJ, ed., Advances in the Psychology of Human Intelligence (Vol. 4). Hillsdale, Erlbaum, pp. 137-179.

Ericsson KA (2003): Exceptional memorizers: Made, not born. Trends in Cognitive Sciences 7: 233-235.

Ericsson KA, Kintsch W (1995): Long-term working memory. Psychological Review 102: 211-245.

Finger S (2000): Minds Behind the Brain: A History of the Pioneers and their Discoveries. Oxford, Oxford University Press.

Flammarion C (1880): Astronomie populaire. Paris, Marpon \& Flammarion.

Flammarion C (1892): Jacques Inaudi. L'illustration 50: 154-155.

Flourens P (1842): Examen de la phrénologie. Paris, Paulin.

Flourens P (1863): De la phrénologie et des études vraies sur le cerveau. Paris, Garnier.

Gall FJ (1819): Anatomie et physiologie du système nerveux en général et du cerveau en particulier (Vol. IV). Paris, Maze.

Gall FJ (1825): Sur les fonctions du cerveau (Vol. V). Paris, Baillière.

Galton F (1880): Visualised numerals. Nature 21: 252-256.

Gasser J (1995): Aux origines du cerveau moderne: Localisations, langage et mémoire dans l'œuvre de Charcot. Paris, Fayard.

George M (1880): Jacques Inaudi, le nouveau Mondeux. Revue Spirite 23: 143-146.

Goetz CG, Bonduelle M, Gelfand T (1995): Charcot: Constructing neurology. New York, Oxford University Press. 
Guida A, Gobet F, Tardieu H, Nicolas S (2012): How chunks, long-term working memory and templates offer a cognitive explanation for neuroimaging data on expertise acquisition: A two-stage framework. Brain and Cognition 79: 221-244.

Hu Y, Ericsson KA, Yang D, Lu C (2009): Superior self-paced memorization of digits in spite of a normal digit span: The structure of a memorist's skill. Journal of Experimental Psychology: Learning, Memory and Cognition 35: 1426-1442.

Hunter IML (1977): Mental calculation. In: Johnson-Laird PN, Wason PC, eds., Thinking: Readings in cognitive science. New York, Cambridge University Press, pp. 35-45.

Inaudi J (1925): Le calcul rapide facile pour tous. Paris, Plantier.

Ioteyko I (1910): Les calculateurs prodiges (avec présentation de Mlle Uranie Diamandi). Revue Psychologique 3: 320-328.

Ioteyko I, Kipiani V (1908): Etude psychologique sur le calculateur P. Diamandi. Revue Psychologique 1: 10-28.

Jackson JH (1864): Loss of speech: Its association with valvular disease of the heart, and with hemiplegia on the right side. Clinical Lectures and Reports by the Medical and Surgical Staff of the London Hospital 1: 388-471.

Jacoby (1846): Biographie de Henri Mondeux, le jeune pâtre calculateur de la Touraine (6e édition). Paris, Charpentier.

JD (1880): Le berger piémontais. Le Monde Illustré 24: 260.

Jost K, Khader PH, Burke M, Bien S, Rösler F (2011): Frontal and parietal contributions to arithmetic fact retrieval: A parametric analysis of the problem-size effect. Human Brain Mapping 32: 51-59.

Kussmaul A (1877): Die Störungen der Sprache. Leipzig, Vogel.

Lahy JM (1913): Une calculatrice-prodige. Etude expérimentale d'un cas de développement exceptionnel de la mémoire des chiffres. Archives de Psychologie 13: 209-243.

Lélut F (1843): Rejet de l'organologie phrénologique de Gall, et de ses successeurs. Paris, Fortin \& Co.

Lévy A (1880): A propos de Jacques Inaudi. Journal de la Jeunesse 16: 223-224.

Manouvrier L (1908): Mémoire visuelle, visualisation colorée. Calcul mental. Notes et études sur Mlle Uranie Diamandi. Bulletins et Mémoires de la Société d'Anthropologie de Paris 9: 584-642.

Menon V, Rivera SM, White CD, Glover GH, Reiss AL (2000): Dissociating prefrontal and parietal cortex activation during arithmetic processing. Neuroimage 12: 357-365.

Miller GA (1956): The magical number seven, plus or minus two. Psychological Review 63: 81-97.

Mitchell FD (1907): Mathematical prodigies. American Journal of Psychology 18: 61-143.

Müller GE (1911): Zur Analyse der Gedächtnistätigkeit und der Vorstellungsverlaufes (I) (Zeitschrift für Psychologie, Ergänzungsband V). Leipzig, Barth.

Müller GE (1917): Zur Analyse der Gedächtnistätigkeit und der Vorstellungverlaufes (II) (Zeitschrift für Psychologie, Ergänzungsband IX). Leipzig, Barth.

Murray DJ, Bandomir CA (2000): G. E. Müller (1911, 1913, 1917) on memory. Psychologie et Histoire, Volume 1, pp. 208-232.

Nicolas S, Gounden Y, Levine Z (2011): The memory of two great mental calculators: Charcot and Binet's neglected 1893 experiments. American Journal of Psychology 124: 235-242.

Nicolas S, Sanitioso RB (2012): Alfred Binet and experimental psychology at the Sorbonne laboratory. History of Psychology 15: 328-363.

Pashler H, McDaniel M, Rohrer D, Bjork R (2009): Learning styles: Concepts and evidence. Psychological Science in the Public Interest 9: 105-119.

Pesenti M, Seron X, Samson D, Duroux B (1999): Basic and exceptional calculation abilities in a calculating prodigy: A case study. Mathematical Cognition 5: 97-148.

Pesenti M, Zago L, Crivello F, Mellet E, Samson D, Duroux B, Seron X, Mazoyer B, TzourioMazoyer N (2001): Mental calculation in a prodigy is sustained by right prefrontal and medial temporal areas. Nature Neuroscience 4: 103-107.

Renneville M (2000): Le langage des crânes: Une histoire de la phrénologie. Paris, Synthélabo.

Ribot T (1881): Les maladies de la mémoire. Paris, Baillière. 
Richardson A (1977): Verbalizer-Visualizer: A cognitive style dimension. Journal of Mental Imagery 1: 109-126.

Richet C (1892): Calcul mental. Revue Scientifique 49: 563-565.

Rickard TC, Romero SG, Basso G, Wharton C, Flitman S, Grafman J (2000): The calculating brain: An fMRI study. Neuropsychologia 38: 325-335.

Samat T (1879): Un nouveau Mondeux au café du Louvre. Le Petit Marseillais, p. 1.

Schiller F (1972/1993): Paul Broca: Founder of French Anthropology, Explorer of the Brain. Oxford, Oxford University Press.

Scripture EW (1891): Arithmetical prodigies. American Journal of Psychology 4: 1-59.

Smith SB (1983): The Great Mental Calculators: The Psychology, Methods, and Lives of Calculating Prodigies, Past and Present. New York, Columbia University Press.

Smith SB (1988): Calculating prodigies. In: Obler LK, Fein D, eds., The Exceptional Brain: Neuropsychology of Talent and Special Abilities. New York, Guilford Press, pp. 19-47.

Squire LR (1987): Memory and the Brain. New York, Oxford University Press.

Squire LR (2004): Memory systems of the brain: A brief review and current perspective. Neurobiology of Learning and Memory 82: 171-177.

Squire LR (2009): Memory and brain systems. Journal of Neuroscience 29: 12711-12716.

Staszewski JJ (1988): Skilled memory and expert mental calculation. In: Chi MTH, Glaser R, Farr MJ, eds., The Nature of Expertise. Hilldale, Erlbaum, pp. 71-128.

Taine H (1870): De l'intelligence. Paris, Hachette.

Tocquet $\mathrm{R}$ (1957): $2+2=4$, les calculateurs prodiges et leurs secrets. Paris, Amiot.

Tulving E (1983): Elements of Episodic Memory. Oxford, Oxford University Press.

Tulving E (1995): Organization of memory: Quo vadis? In: Gazzaniga MS, ed., The Cognitive Neurosciences. Cambridge, MIT Press, pp. 839-847.

Tulving E (2007): Are there 256 kinds of memory? In: Nairne JS, ed., The Foundations of Remembering: Essays in Honor of Henry L. Roediger, III. New York, Psychology Press, pp. $39-52$.

Wernicke C (1874): Der aphasische Symptomenkomplex. Breslau, Cohn \& Weigert.

Wilding JM, Valentine ER (1997): Superior memory. Hove, Psychology Press.

Wilding JM, Valentine ER (2006): Exceptional memory. In: Ericsson KA, Charness N, Feltovich P, Hoffman RR, eds., Cambridge Handbook of Expertise and Expert Performance. Cambridge, Cambridge University Press, pp. 539-552. 